\title{
EFFECT OF CRUDE PALM OIL PROTECTION WITH FORMALDEHYDE ON HYDROGENATION OF RUMEN FLUID UNSATURATED FATTY ACID: ITS EFFECT ON BLOOD AND MEAT FATTY ACID
}

\author{
Nafly C. Tiven ${ }^{1, *}$, Lies Mira Yusiati ${ }^{2}$, Rusman $^{2}$, and Umar Santoso ${ }^{3}$ \\ ${ }^{1}$ Faculty of Agriculture, Pattimura University, Jl. Ir. M. Putuhena Ambon 97233 \\ ${ }^{2}$ Faculty of Animal Science and Industries, Universitas Gadjah Mada, Jl. Fauna 3 Yogyakarta 55281 \\ ${ }^{3}$ Faculty of Agriculture Technology, Universitas Gadjah Mada, Jl. Sosio Yustisia, Yogyakarta. 55281
}

Received November 21, 2012; Accepted June 28, 2013

\begin{abstract}
This research aimed to determine the effect of crude palm oil protected with formaldehyde on the hydrogenation of unsaturated fatty acids in the rumen and its effect on blood and meat fatty acids. Fifteenth local male lambs aged 9-12 months weighing 14-17 kg, were divided into 3 groups ration treatment. The first group received only the basal ration (R0), the $2^{\text {nd }}$ group received the basal ration and $3 \% C P O(R 1)$, while the $3^{\text {rd }}$ group received the basal ration and 3\% CPO protected with $2 \%$ formaldehyde (R2). Basal feed consisted of $60 \%$ grass, $30 \%$ bran and $10 \%$ soybean meal, with the nutrient content of $62.98 \%$ TDN, $45.5 \%$ DM, $14.48 \%$ CP, $4.70 \%$ EE and 21.93\% CF. Parameters observed were the fatty acid from rumen fluid, blood and meat of sheep. Data were analyzed by complete randomized design direction patterns. Differences between treatments were tested further using Duncan's New Multiple Range Test. The results showed that treatment of R2 can increase unsaturated fatty acids in the rumen, blood and meat $(P<0.01)$. Concluded that the protection of crude palm oil in the ration with formaldehyde can reduce the hydrogenation of unsaturated fatty acids by rumen microbes, which affects the increase in unsaturated fatty acids, both in blood and in the meat.
\end{abstract}

Keywords: rumen fluid fatty acid; blood fatty acid; meat fatty acid

\section{ABSTRAK}

Penelitian ini bertujuan untuk mengetahui pengaruh proteksi minyak sawit kasar dengan formaldehid terhadap hidrogenasi asam lemak tidak jenuh dalam rumen dan dampaknya terhadap asam lemak darah dan daging. Sebanyak 15 ekor ternak domba lokal jantan umur 9-12 bulan dengan bobot badan sekitar 13-17 kg, dibagi menjadi 3 kelompok perlakuan pakan. Kelompok ternak pertama hanya mendapat ransum basal (RO), kelompok kedua mendapat ransum basal dan 3\% CPO tanpa diproteksi formaldehid (R1) serta kelompok ketiga mendapat ransum basal dan 3\% CPO yang diproteksi dengan 2\% formaldehid (R2). Ransum basal yang digunakan terdiri dari $60 \%$ rumput gajah, 30\% bekatul dan 10\% bungkil kedele, dengan kandungan nutrien 62,98\% TDN; 45,5\% BK; 14,48\% PK; 4,70\% LK dan 21,93\% SK. Parameter yang diamati adalah asam lemak cairan rumen, darah dan daging domba. Data yang diperoleh dianalisis dengan rancangan acak lengkap pola sederhana. Perbedaan antar perlakuan diuji lanjut menggunakan Duncan's New Multiple Range Test. Hasil penelitian menunjukkan bahwa perlakuan R2 dapat meningkatkan asam lemak tidak jenuh dalam rumen, darah dan daging $(P<0.01)$. Dari penelitian ini dapat disimpulkan bahwa proteksi minyak sawit kasar dengan formaldehid dalam ransum dapat mengurangi hidrogenasi asam lemak tidak jenuh oleh mikrobia rumen, yang berdampak pada peningkatan asam lemak tidak jenuh, baik dalam darah maupun dalam daging.

Kata Kunci: asam lemak cairan rumen; asam lemak darah; asam lemak daging

\section{INTRODUCTION}

Crude palm oil (CPO) extracted from palm fruit mesocarp [1], has high content in polyunsaturated fatty acids (PUFA). The composition of fatty acids in palm oil are $0.50 \%$ lauric acid (C12:0), 0.92\% myristic acid
(C14:0), 36.84\% palmitic acid (C16:0), 4.77\% stearic acid (C18:0), $44.51 \%$ oleic (C18:1), $11.12 \%$ linoleic acid (C18:2) and $0.24 \%$ linolenic acid (C18:3) [2]. Palm oil contains saturated fatty acids (SAFA), namely C16:0 $44.3 \%$, C18:0 4.6\%, C14:0 1.0\%, monounsaturated fatty acids (MUFA), namely C18: $138.7 \%$, and poly-

* Corresponding author. Tel/Fax : +62-81328668298

Email address : nafly_tiven@yahoo.co.id

Nafly C. Tiven et al. 

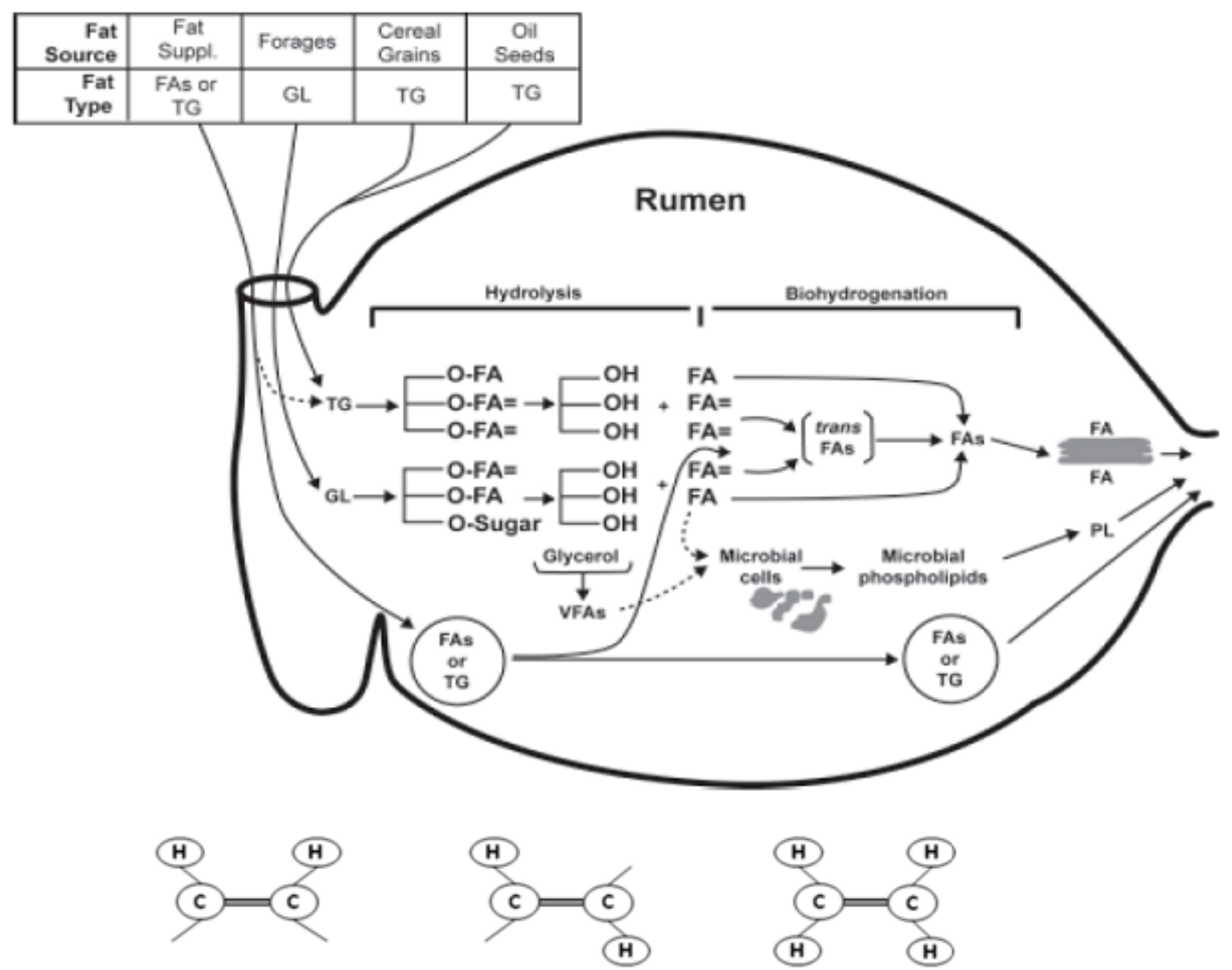

cis oriented double bond

trans oriented double bond
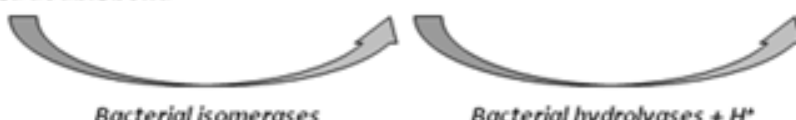

Fig 1. Illustration hydrogenation of unsaturated fatty acids

unsaturated fatty acids (PUFAs), namely C18:2 10.5\% and other $0.9 \%$ [3]. The high unsaturated fatty acid in CPO can be used as a source of unsaturated fatty acids in the diet. The diet which is supplemented with fats rich in polyunsaturated fatty acids may increase the polyunsaturated fatty acids in meat [4], so that it can decrease cholesterol level and also reducing the risk of coronary heart disease in consumers [5-6].

There is a difference between ruminants and nonruminants in the process of digestion and absorption of fat, due to the large differences of fat metabolism in the rumen. Fat digestion in the rumen (1) hydrolysis/lipolysis, the breakdown of fatty acid ester bond, (2) fermentation of glycerol released from hydrolysis of the rumen to VFA (Volatile Fatty Acid), and (3) hydrogenation of saturated fatty acids by rumen microbes. Hydrolysis of ester bonds is the first step is carried out primarily by bacteria Anaerovibrio lipolytica (hydrolyzes triglycerides) and Butyrivibrio fibrisolvens (hydrolyzes phospholipids and glycolipids), while the hydrogenation of unsaturated fatty acids is the next step, the main substrate is $C 18: 2$ and $C 18: 3$ with each level of the hydrogenation about $70-95 \%$ and $85-100 \%$ [7] (Fig. 1). This condition causes the linoleic acid (cis9, cis-12-18: 2) and linolenic acid (cis-9, cis-12, cis-1518:3) in the diet, to be found in the meat with low concentrations [8], which is only about $10 \%$ remained in the lipid tissues [9] while $90 \%$ is hydrogenated to C18:0 [7]. Hydrogenation of unsaturated fatty acids can not be fully carried out only by a single species of bacterium, so bacteria are divided into two groups based on the final product of hydrogenation, namely group A (hydrogenation C18:2 and C18:3 with the final product trans-C18:1), and group B (hydrogenation trans-C18:1 with the final product C18:0) [7] (Fig. 2).

One way to prevent rumen microbial hydrogenation is to protect the feed material source of unsaturated fatty acids in the diet with formaldehyde 


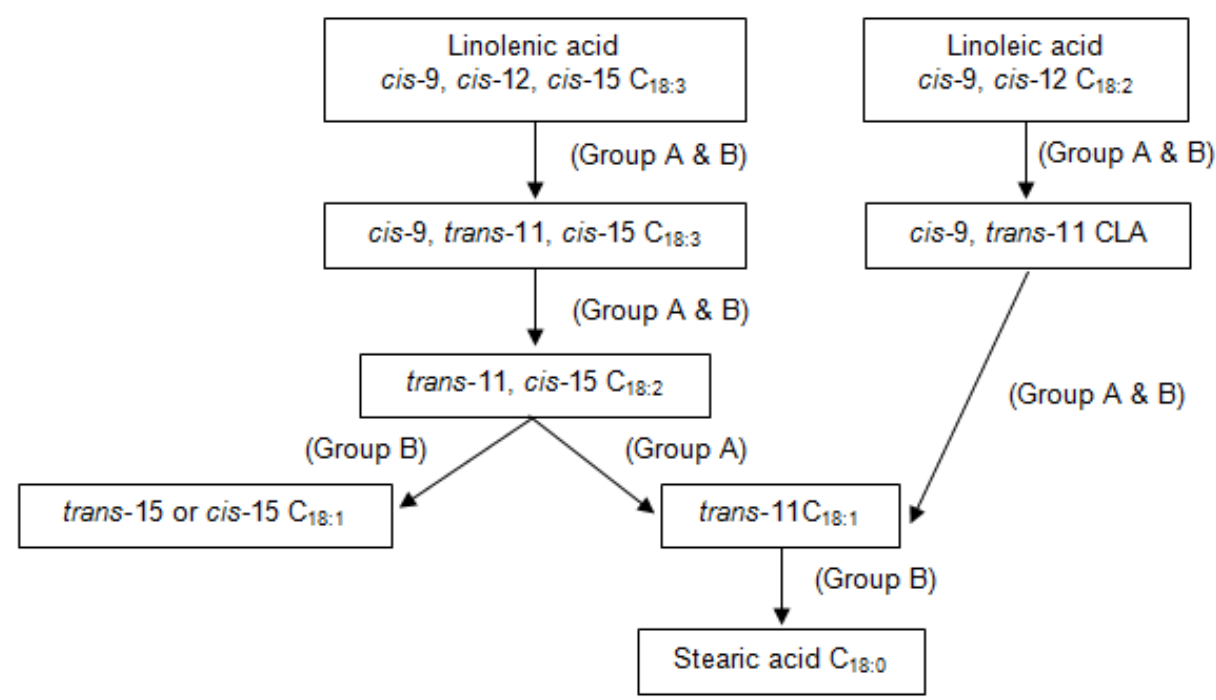

Fig 2. Hydrogenation pathway of linoleic $(\mathrm{C} 18: 2)$ and linolenic $(\mathrm{C} 18: 3)$ by the rumen bacteria [7]

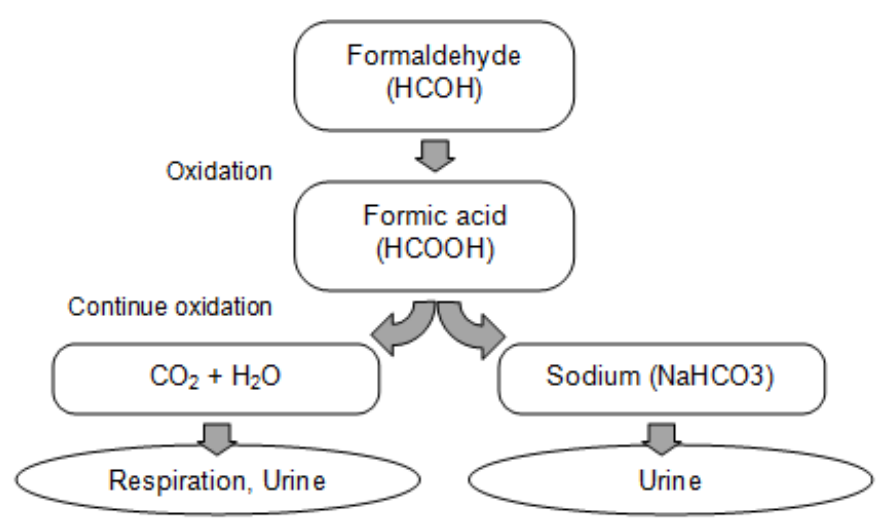

Fig 3. Process detoxification of formaldehyde [13]

$\left(\mathrm{CH}_{2} \mathrm{O}\right)$. Feed treatment with formaldehyde can decrease the proportion of C12:0, C14:0, C16:0 and increase C18:1, C18:2 and C18:3 [10], and C20:4, EPA and DHA, but decrease total triglycerides and cholesterol content in sheep [11]. In addition to protecting unsaturated fatty acids, the formaldehyde was chosen because it is cheap, easy to make, and relatively harmless. When absorbed in the blood, formaldehyde will be metabolized to formic acid then excreted through the urine as the sodium salt or further oxidized to $\mathrm{CO}_{2}$ and $\mathrm{H}_{2} \mathrm{O}$ [12] (Fig. 3).

About $3 \%$ of CPO mixed with expired milk powder (1:2) and protected with $2 \%$ technical formaldehyde of the ingredients are mixed and tested in vitro. This treatment can protect $\mathrm{C} 18: 1$ and C18: 2 from rumen microbial hydrogenation [13], have no negative effect on rumen fermentation parameters and microbial activity [14]. The results were supplemented in the ration and tested in vivo to determine its effect on the hydrogenation of unsaturated fatty acids of rumen fluid and its effect on blood and meat fatty acid.

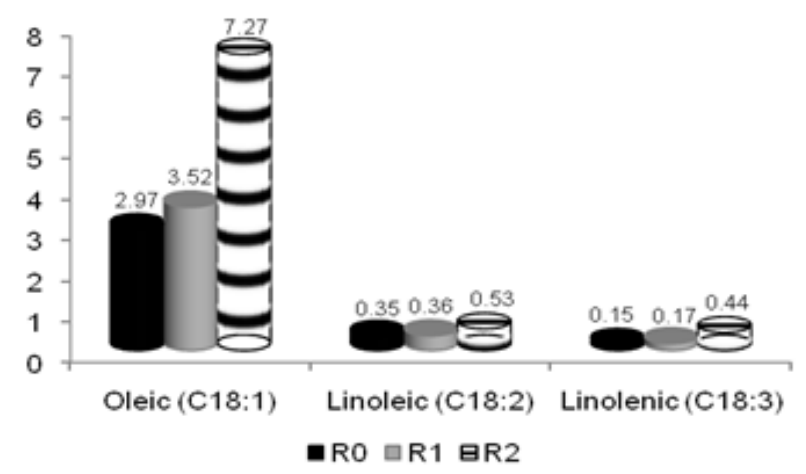

Fig 4. Comparison of increase rumen fluid unsaturated fatty acids of sheep between treatments $\mathrm{R} 2$ with $\mathrm{R} 1$ and $\mathrm{R} 0$

\section{EXPERIMENTAL SECTION}

\section{Materials}

The materials of this research are CPO, expired SGM milk powder. Rumen fluid was taken from male local sheep using Trocar, 37\% technical formaldehyde, chloroform and methanol mixture (2:1), $0.88 \% \mathrm{NaCl}$ and $\mathrm{Na}_{2} \mathrm{SO}_{4}$ anhydrous. Basal diet consisted of $60 \%$ elephant grass, $30 \%$ bran and $10 \%$ soybean meal. Nutrient content of basal diet was $62.98 \%$ TDN; $45.5 \%$ $\mathrm{DM} ; 14.48 \% \mathrm{CP} ; 4.70 \% \mathrm{~F}$ and $21.93 \% \mathrm{CF}$.

\section{Instrumentation}

Instrumentation of this research included are a set of Trocar for sucking rumen fluid, gas chromatography (GC) Shimadzu GC-2010, analytical balance, water bath, filter paper, sterile disposable needles, and test tubes. 
Table 1. Rumen fluid fatty acids content ( $\mathrm{g} / 100 \mathrm{~g}$ fat) of sheep with the diet addition of CPO protected

\begin{tabular}{lrrr}
\hline \multirow{2}{*}{ Fatty acids } & \multicolumn{3}{c}{ Treatments } \\
\cline { 2 - 4 } & \multicolumn{1}{c}{$\mathrm{R} 0$} & \multicolumn{1}{c}{$\mathrm{R} 1$} & $\mathrm{R} 2$ \\
\hline Lauric (C12:0) & $0.14^{\mathrm{e}} \pm 0.03$ & $0.91^{\mathrm{c}} \pm 0.06$ & $0.70^{\mathrm{d}} \pm 0.16$ \\
Myristic (C14:0) & $1.46^{\mathrm{e}} \pm 0.05$ & $4.29^{\mathrm{c}} \pm 0.71$ & $3.29^{\mathrm{d}} \pm 0.23$ \\
Palmitic (C16:0) & $14.12^{\mathrm{d}} \pm 0.28$ & $38.61^{\mathrm{c}} \pm 2.70$ & $34.02^{\mathrm{c}} \pm 3.91$ \\
Stearic (C18:0) & $28.01^{\mathrm{e}} \pm 0.32$ & $50.39^{\mathrm{c}} \pm 3.07$ & $41.71^{\mathrm{d}} \pm 6.71$ \\
Oleic (C18:1) & $2.97^{\mathrm{d}} \pm 0.29$ & $3.52^{\mathrm{d}} \pm 0.32$ & $7.27^{\mathrm{c}} \pm 0.43$ \\
Linoleic (C18:2) & $0.35^{\mathrm{d}} \pm 0.02$ & $0.36^{\mathrm{d}} \pm 0.03$ & $0.53^{\mathrm{c}} \pm 0.07$ \\
Linolenic (C18:3) & $0.15^{\mathrm{b}} \pm 0.06$ & $0.17^{\mathrm{b}} \pm 0.02$ & $0.44^{\mathrm{a}} \pm 0.15$ \\
SFA & $43.73^{\mathrm{e}} \pm 0.63$ & $94.20^{\mathrm{c}} \pm 6.28$ & $79.72^{\mathrm{d}} \pm 10.17$ \\
MUFA & $2.97^{\mathrm{d}} \pm 0.29$ & $3.52^{\mathrm{d}} \pm 0.32$ & $7.27^{\mathrm{c}} \pm 0.43$ \\
PUFA & $0.50^{\mathrm{d}} \pm 0.06$ & $0.53^{\mathrm{d}} \pm 0.05$ & $0.97^{\mathrm{c}} \pm 0.10$ \\
Total & $47.20^{\mathrm{d}} \pm 0.73$ & $98.25^{\mathrm{c}} \pm 6.00$ & $87.96^{\mathrm{c}} \pm 9.76$ \\
\hline
\end{tabular}

\section{Procedure}

de : different superscripts in the same row indicate significant $(P<0.01)$

\section{Livestock}

As many as 15 local male sheep's 9-12 months old with body weigh approximately $13-17 \mathrm{~kg}$, maintained in individual cages shaped stage equipped with places to eat and drink. The sheep were divided into 3 groups according to the treatment of feed. The first group received only the basal diet (RO), the $2^{\text {nd }}$ group received the basal diet and 3\% CPO (R1), while the $3^{\text {rd }}$ group received the basal diet and 3\% CPO protected with 2\% formaldehyde (R2). The sheep were maintained for 3 months and were given rations approximately $4.3 \%$ from body weight twice a day, at 08.00 a.m. and at 15.00 p.m., while the drinking water supplied by ad libitum. During maintenance, the amount of daily consumption of each animal is recorded, and then weighed once a week to determine the weight and adjust the amount of feed given. For data digestibility, a collection made for one week.

\section{Fatty acid tested}

At the end of the data collection, $100 \mathrm{~mL}$ of rumen fluid was taken using trocar and transferred into an Erlenmeyer flask. The rumen fluid was added with $50 \mathrm{~mL}$ of chloroform and methanol (2:1) mixture and allowed to stand. The bottom layer was taken and filtered. The filtrate was added with $10 \mathrm{~mL} 0.88 \% \mathrm{NaCl}$ and allowed to stand. The bottom layer was filtered through filter paper containing $\mathrm{Na}_{2} \mathrm{SO}_{4}$ anhydrous to bind water, and then was blown with $\mathrm{N}_{2}$. The resultant fat was prepared for the determination of methylated fatty acids and the fatty acid composition by gas chromatography method [15].

Before slaughtering, the blood was taken through the jugular vein using a sterile disposable needle and put in a test tube. Ten $\mathrm{g}$ of fresh blood were extracted and methylated in order to determine the fatty acid composition by gas chromatography method [15]. For the determination of meat fatty acids, $10 \mathrm{~g}$ of meat from Longissimus dorsi muscle (LD) were used. The fat from meat was extracted and methylated for the determination of the fatty acid composition by gas chromatography method [15]. Fatty acids of rumen fluid, blood and flesh were analyzed for the C12:0, C14:0, C16:0, C18:0, C18:1, C18:2 and C18:3.

\section{Statistical analysis}

The data obtained were analyzed with analysis of variance using one way completely randomized design, with 3 ration treatment, namely the basal ration (R0), the basal ration and 3\% CPO without formaldehyde treatment (R1) and the basal ration and 3\% CPO protected with $2 \%$ formaldehyde (R2). Differences between treatments were tested further by Duncan's New Multiple Range Test. Data processing was done with the program SPSS 17.0 for Windows Evaluation Version.

\section{RESULT AND DISCUSSION}

\section{Effect of Crude Palm Oil Protected on Rumen Fluid Fatty Acid}

Effect of crude palm oil protection on sheep rumen fluid fatty acid can be seen in Table 1 . The results showed that the addition of CPO (R1) increased rumen fluid total fatty acid $(P<0.01)$ of $51.05 \mathrm{~g} / 100 \mathrm{~g}$ compared to sheep which were given only the basal ration (R0). This was influenced by an increasing of SFA $(P<0.01)$ at $50.47 \mathrm{~g} / 100 \mathrm{~g}$, namely $\mathrm{C} 12: 0, \mathrm{C} 14: 0$, $\mathrm{C} 16: 0$ and $\mathrm{C} 18: 0$. When viewed as a partial, $\mathrm{C} 18: 0$ is a highest fatty acid. This proves that hydrogenation process on unsaturated fatty acids to saturated fatty acids, namely $\mathrm{C} 18: 0$, in the rumen occurred. Hydrogenation of unsaturated fatty acids causes a reduction of cis-9 double bond into trans-11 fatty acids, and then trans- 11 double bond is hydrogenated further to produce C18:0 [7].

The addition of CPO protected with formaldehyde (R2) increased the total fatty acids $(P<0.01)$ at $40.76 \mathrm{~g} / 100 \mathrm{~g}$ compared to sheep which were given only 
Table 2. Blood fatty acids content ( $\mathrm{g} / 100 \mathrm{~g}$ fat) of sheep with the diet addition of CPO protected

\begin{tabular}{lrrr}
\hline \multirow{2}{*}{ Fatty acids } & \multicolumn{3}{c}{ Treatments } \\
\cline { 2 - 4 } & \multicolumn{1}{c}{$\mathrm{R} 0$} & \multicolumn{1}{c}{$\mathrm{R} 1$} \\
\hline Lauric (C12:0) & $0.15^{\mathrm{a}} \pm 0.02$ & $0.15^{\mathrm{a}} \pm 0.05$ & $0.05^{\mathrm{b}} \pm 0.03$ \\
Miristic (C14:0) & $1.22^{\mathrm{d}} \pm 0.09$ & $1.43^{\mathrm{c}} \pm 0.10$ & $1.11^{\mathrm{d}} \pm 0.06$ \\
Palmitic (C16:0) & $18.33^{\mathrm{c}} \pm 0.66$ & $18.70^{\mathrm{c}} \pm 0.68$ & $13.37^{\mathrm{d}} \pm 0.79$ \\
Stearic (C18:0) & $16.53^{\mathrm{c}} \pm 1.37$ & $16.63^{\mathrm{c}} \pm 1.50$ & $10.21^{\mathrm{d}} \pm 0.78$ \\
Oleic (C18:1) & $23.49^{\mathrm{d}} \pm 1.25$ & $22.42^{\mathrm{d}} \pm 2.01$ & $27.54^{\mathrm{c}} \pm 0.57$ \\
Linoleic (C18:2) & $0.90^{\mathrm{b}} \pm 0.11$ & $0.97^{\mathrm{b}} \pm 0.02$ & $1.13^{\mathrm{a}} \pm 0.03$ \\
Linolenic (C18:3) & $0.11^{\mathrm{e}} \pm 0.05$ & $0.27^{\mathrm{d}} \pm 0.08$ & $1.12^{\mathrm{c}} \pm 0.03$ \\
SFA & $36.23^{\mathrm{c}} \pm 1.10$ & $36.91^{\mathrm{c}} \pm 2.04$ & $24.74^{\mathrm{d}} \pm 1.51$ \\
MUFA & $23.49^{\mathrm{d}} \pm 1.25$ & $22.42^{\mathrm{d}} \pm 2.01$ & $27.54^{\mathrm{c}} \pm 0.57$ \\
PUFA & $1.01^{\mathrm{e}} \pm 0.12$ & $1.24^{\mathrm{d}} \pm 0.08$ & $2.25^{\mathrm{c}} \pm 0.03$ \\
Total & $60.73^{\mathrm{a}} \pm 2.18$ & $60.57^{\mathrm{a}} \pm 3.08$ & $54.53^{\mathrm{b}} \pm 1.11$ \\
\hline
\end{tabular}

$\mathrm{ab}$ : different superscripts in the same row indicate significant $(\mathrm{P}<0.05)$

cde : different superscripts in the same row indicate significant $(P<0.01)$.

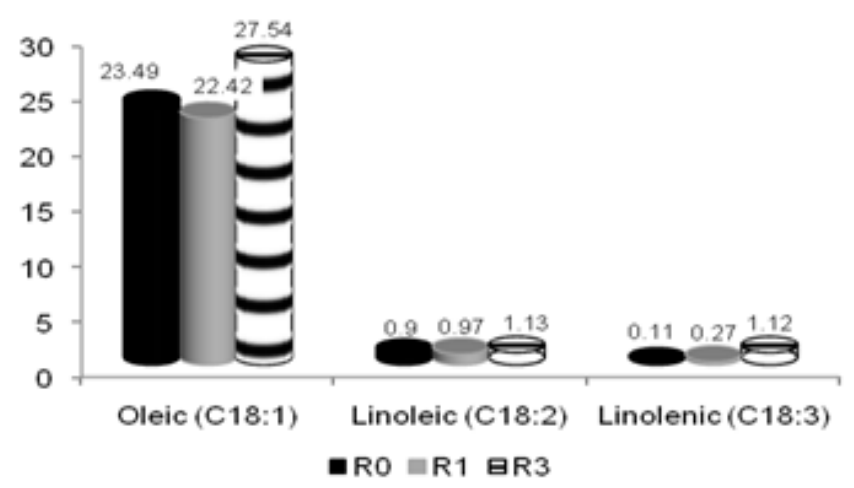

Fig 5. Comparison of increase blood unsaturated fatty acids of sheep between treatments R2 with R1 and R0

the basal ration (R0). It is affected by the increase of SFA, MUFA and PUFA $(P<0.01)$ at $35.99 \mathrm{~g} / 100 \mathrm{~g}$, $4.30 \mathrm{~g} / 100 \mathrm{~g}$ and $0.47 \mathrm{~g} / 100 \mathrm{~g}$, respectively. In comparison with R1 treatment, R2 treatment tends to decrease the total fatty acids but not significant. Treatment of R2 decreased SFA $(P<0.01)$ at $14.48 \mathrm{~g} / 100 \mathrm{~g}$, but increased the MUFA and PUFA $(P<0.01)$, at $3.75 \mathrm{~g} / 100 \mathrm{~g}$ and $0.44 \mathrm{~g} / 100 \mathrm{~g}$, respectively. Unsaturated fatty acids increased in rumen fluid in R2 treatments as compared with R1 and R0, as shown in Fig. 4. The increasing of PUFA and MUFA of R2 treatment suggests that protection of CPO with formaldehyde may prevent the hydrogenation of unsaturated fatty acids by rumen microbes, suggesting that feed ingredients that is protected with formaldehyde will be resistant to rumen microbial degradation.

\section{Effect of Protected Crude Palm Oil on Blood Fatty Acid}

Effect of protected crude palm oil on blood fatty acid of sheep can be seen in Table 2. The results showed that the addition of CPO (R1) causes insignificant increase of the total fatty acids, SFA and MUFA, but increased the PUFA $(P<0.01)$, when compared with sheep that were given only the basal ration (R0). The increasing of PUFA caused by $\mathrm{C} 18: 3$ $(P<0.01)$, which escaped from the rumen microbial hydrogenation. There are about $10 \%$ linoleic acid (cis9, cis-12-18:2) and linolenic acid (cis-9, cis-12, cis-1518:3) remains in the feed and escapes from the rumen microbial hydrogenation [9].

When compared to sheep which were given only the basal ration (R0) and the addition of CPO (R1), total fatty acids decreased $(P<0.05)$ by $6.20 \mathrm{~g} / 100 \mathrm{~g}$ and $6.04 \mathrm{~g} / 100 \mathrm{~g}$, respectively when sheep were given ration with the addition of protected CPO with formaldehyde (R2). That was caused the decrease in SFA $(P<0.01)$, at $11.49 \mathrm{~g} / 100 \mathrm{~g}$ and $12.17 \mathrm{~g} / 100 \mathrm{~g}$, respectively, which is caused by a decrease in C12:0, $C 14: 0, C 16: 0$ and $C 18: 0(P<0.01)$. The treatment of R2 increased MUFA $(P<0.01)$, by $4.05 \mathrm{~g} / 100 \mathrm{~g}$ and $5.12 \mathrm{~g} / 100 \mathrm{~g}$, respectively and increase PUFA $(P<0.01)$, by $1.24 \mathrm{~g} / 100 \mathrm{~g}$ and $1.01 \mathrm{~g} / 100 \mathrm{~g}$, respectively. Comparison of the increase of unsaturated fatty acids in blood between R2 treatments with R1 and with R0 can be seen in Fig. 5. The increase in MUFA and PUFA caused by an increase of $C 18: 1, C 18: 2$ and $C 18: 3(P<0.01)$ on the $R 2$ treatment as compared to R0 and R1 treatment.

\section{Effect of Protected Crude Palm Oil on Meat Fatty Acid}

Effect of protected crude palm oil on meat fatty acid of sheep can be seen in Table 3 . The results showed that the addition of CPO (R1) in the diet was not significant to the meat total fatty acids compared to the basal ration (RO). The addition of CPO and protected with formaldehyde (R2) decreased meat total fatty acids $(P<0.05)$, of $2.99 \mathrm{~g} / 100 \mathrm{~g}$ and $4.51 \mathrm{~g} / 100 \mathrm{~g}$, respectively compared to sheep which were fed only the basal ration (R0) and the addition of the CPO (R1), which caused the decrease of SFA $(P<0.01)$ due to the decrease in $C 16: 0$ and $C 18: 0(P<0.01)$. Treatment of R2 
Table 3. Meat fatty acids content ( $\mathrm{g} / 100 \mathrm{~g}$ fat) of sheep with the diet addition of CPO protected

\begin{tabular}{lrrr}
\hline \multirow{2}{*}{ Fatty acids } & \multicolumn{3}{c}{ Treatments } \\
\cline { 2 - 4 } & \multicolumn{1}{c}{$\mathrm{R} 0$} & \multicolumn{1}{c}{$\mathrm{R} 1$} & $\mathrm{R} 2$ \\
\hline Lauric (C12:0) & $0.09^{\mathrm{e}} \pm 0.01$ & $0.16^{\mathrm{c}} \pm 0.00$ & $0.12^{\mathrm{d}} \pm 0.02$ \\
Miristic (C14:0) & $2.88^{\mathrm{ab}} \pm 0.29$ & $3.2^{\mathrm{a}} \pm 0.51$ & $2.27^{\mathrm{b}} \pm 0.14$ \\
Palmitic (C16:0) & $16.54^{\mathrm{b}} \pm 0.39$ & $19.81^{\mathrm{a}} \pm 1.80$ & $14.25^{\mathrm{b}} \pm 1.94$ \\
Stearic (C18:0) & $15.36^{\mathrm{e}} \pm 0.48$ & $14.75^{\mathrm{c}} \pm 0.77$ & $9.66^{\mathrm{d}} \pm 0.04$ \\
Oleic (C18:1) & $17.72^{\mathrm{b}} \pm 1.48$ & $16.15^{\mathrm{b}} \pm 2.15$ & $23.16^{\mathrm{a}} \pm 2.32$ \\
Linoleic (C18:2) & $0.23^{\mathrm{d}} \pm 0.02$ & $0.26^{\mathrm{d}} \pm 0.02$ & $0.32^{\mathrm{c}} \pm 0.03$ \\
Linolenic (C18:3) & $0.09^{\mathrm{d}} \pm 0.02$ & $0.10^{\mathrm{d}} \pm 0.01$ & $0.14^{\mathrm{c}} \pm 0.01$ \\
SFA & $34.87^{\mathrm{c}} \pm 0.45$ & $37.92^{\mathrm{c}} \pm 2.55$ & $26.30^{\mathrm{d}} \pm 2.05$ \\
MUFA & $17.72^{\mathrm{d}} \pm 1.48$ & $16.15^{\mathrm{d}} \pm 2.15$ & $23.16^{\mathrm{c}} \pm 2.32$ \\
PUFA & $0.32^{\mathrm{d}} \pm 0.03$ & $0.36^{\mathrm{d}} \pm 0.02$ & $0.46^{\mathrm{c}} \pm 0.04$ \\
Total & $52.91^{\mathrm{a}} \pm 1.49$ & $54.43^{\mathrm{a}} \pm 0.58$ & $49.92^{\mathrm{b}} \pm 1.63$ \\
\hline
\end{tabular}

$\mathrm{ab}$ : different superscripts in the same row indicate significant $(\mathrm{P}<0.05)$

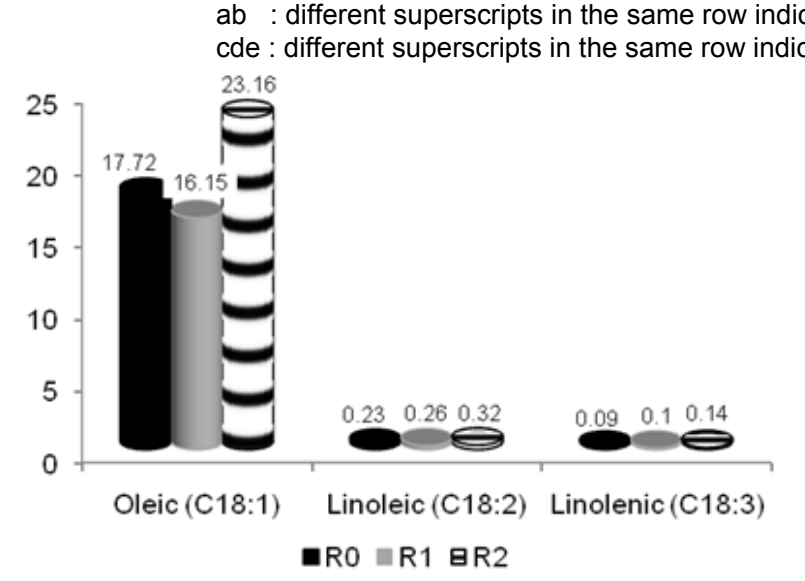

Fig 6. Comparison of increase meat unsaturated fatty acids of sheep between treatments R2 with R1 and R0

also increased MUFA and PUFA $(P<0.01)$, namely C18:1, C18:2 and C18:3. Comparison of the increase of meat unsaturated fatty acids between R2 treatments with R1 and R0 can be seen in Fig. 6. Supplementation of soybean oil and tuna oil $(70: 30)$ protected with formaldehyde (PTO) in sheep lactation diet can decrease C16:0 from $302 \mathrm{~g} / \mathrm{kg}$ (control) to $296 \mathrm{~g} / \mathrm{kg}$ (PTO), C18:0 out of $12 \mathrm{~g} / \mathrm{kg}$ (control) to $8.6 \mathrm{~g} / \mathrm{kg}$ (PTO), but increase $C 18: 2$ is almost twice that of $29 \mathrm{~g} / \mathrm{kg}$ (control) to $56 \mathrm{~g} / \mathrm{kg}$ (PTO) and C18:3 of $8 \mathrm{~g} / \mathrm{kg}$ (control) to $13 \mathrm{~g} / \mathrm{kg}$ (PTO) of milk fat [16]. Protection of tuna oil with formaldehyde decreases $\mathrm{C} 18: 0$, but increases C18:1 and C18:2 in the sheep meat [13]. Protection of fat using a casein-formaldehyde (Canola Lipid) can decrease $C 14: 0, C 16: 0$ and $C 18: 0$, but increase C18:1, C18:2 and C18:3 in adipose tissue of Brangus cattle [17].

\section{CONCLUSION}

Protection of crude palm oil with formaldehyde can decrease the hydrogenation of unsaturated fatty acids by rumen microbes, indicating a positive impact for the increase of unsaturated fatty acids in the blood and meat.

\section{ACKNOWLEDGEMENT}

The authors would like to thank you PT. Indofood, Tbk, for the financial support through the Indofood Riset Nugraha Program (IRN) 2011.

\section{REFERENCES}

1. Loi, C.C., Boo, H.C., Mohammed, A.S., and Ariffin, A.A., 2011, J. Food Chem., 128, 1, 223-226.

2. Sampaio, K.A., Ceriani, R., Silva, S.M., Taham, T., and Meirelles, A.J.A., 2011, Food Bioprod. Process., 89, 4, 383-390.

3. Mukherjee, S., and Mitra, A., 2009, J. Hum. Ecol., 26, 3, 197-203.

4. Felton, E.E.D., and Kerley, M.S., 2004, J. Anim. Sci., 82, 3, 725-732.

5. Willett, W.C., 2007, J. Cardiovasc. Med., 8, Suppl. 1, S42-S45.

6. Harris, W., 2010, Curr. Opin. Clin. Nutr. Metab. Care, 13, 2, 125-129.

7. Bauman, D.E., Perfield, J.W., de Veth, M.J., and Lock, A.L., 2003, New perspectives on lipid digestion and metabolism in ruminants, Proc. Cornell Nutr. Conf. Feed Manuf., Syracuse, NY, Cornell Univ., Ithaca, NY, 175-189.

8. Jenkins, T.C., Wallace, R.J., Moate, P.J., and Mosley, E.E., 2008, J. Anim. Sci., 86, 2, 397-412.

9. Wood, J.D., Enser, M., Fisher, A.V., Nute, G.R., Sheard, P.R., Richardson, R.I., Hughes, S.I., and Whittington, F.M., 2008, Meat Sci., 78, 4, 343-358.

10. de Veth, M.J., Gulati, S.K., Luchini, N.D., and Bauman, D.E., 2005, J. Dairy Sci., 88, 5, 16851693.

11. Kitessa, S.M., Gulati, S.K., Ashes, J.R., Fleck, E., Scott, T.W., and Nichols, P.D., 2001, J. Anim. Feed Sci. Technol., 89, 3, 189-199.

12. Wartew, G.A., 1983, J. Appl. Toxicol., 3, 3, $121-$ 126.

13. Tiven, N.C., Yusiati, L.M., Rusman, and Santoso, U., 2011, Indo. J. Chem., 11, 1, 43-47. 
14. Tiven, N.C., Yusiati, L.M., Rusman, and Santoso, U., 2011, Media Peternakan, 34, 1, 42-49.

15. AOAC, 2005, Official methods of analysis, $11^{\text {th }}$ ed., Association of Official Analytical Chemists, Washington, DC.
16. Kitessa, S.M., Peake, D., Bencini, R., and Williams, A.J., 2003, J. Anim. Feed Sci. Technol., 108, 1-4, 1-14.

17. Gilbert, C.D., Lunt, D.K., Miller, R.K., and Smith, S.B., 2003, J. Anim. Sci., 81, 10, 2457-2468. 